\title{
Witchcraft Accusations: A Challenge for Families, Communities, and Churches in Africa
}

\author{
Boubakar Sanou
}

\section{Introduction}

According to Timothy Stabell, "witchcraft continues to be a topic that stirs passions and fears in many places around the world" (Stabell 2010, 460). This is particularly true of Africa where the belief in witchcraft is so pervasive that it can be viewed as a commonplace feature of many African spiritual beliefs (Ellis and ter Haar 2004, 27). From a traditional African perspective, there is an undeniable connection between the material and spiritual worlds. This worldview supports the idea that there are spiritual reasons for all ordinary everyday occurrences (Mbiti 1990, 151).

Witchcraft is generally defined as the ability of a person or group of people to cause harm to others by use of supernatural powers (Hutton 2006, 211; Nyaga 2007, 247). Generally speaking, witchcraft is any type of evil that negatively affects the fulfillment of human life (Akrong 2007, 59). In many African contexts, there is often a very thin line between the ideas of evil spirits, magic, sorcery, spell casting, and curses and the idea of witches or witchcraft (Quarmyne 2011, 477; Danfulani 2007, 477). Because witchcraft is directed against others, it is generally perceived as "the anti-social crime par excellence" (Mencej 2015, 112). Witchcraft is believed to be against the preservation of life which is the most central precept of African life. Therefore, fighting against witchcraft is considered a moral imperative for all those affected by it (Magoola 2012, 99-100). As a result of the perception people hold on witchcraft, they often treat with the greatest cruelty those suspected to be associated with it, even wishing to physically eliminate them from society (Nyabwari and Kagema 2014, 9).

Witchcraft beliefs and accusations negatively impact family relationships as well as other networks of social relations (Akrong 2007, 58; and Harries 2012, 129139). In connection with Priest, Ngolo and Stabell's article (2020), this one further explores the issue of witchcraft accusations and offers some recommendations as a Christian response to the phenomenon.

\section{Witchcraft in African Cosmological Thought}

The belief in witchcraft is a strong and widespread phenomenon on the continent of Africa (ter Haar 2007, 1; Ntloedibe-Kuswani 2007, 205). Belief in supernatural powers and witchcraft are such widespread components of the worldview of many Africans across all social lines that it is no longer only a village affair. It is held by people of diverse education and religious affiliation in rural as well as in urban settings (Hinfelaar 2007, 229). It can therefore be argued that in Africa, the belief in witchcraft is a religio-cultural phenomenon. Elom Dovlo notes that "although the belief in witchcraft is part of traditional religious belief, Islam and Christianity in their development have accepted the worldview that supports the belief system by providing preventive and curative measures against witchcraft attacks and by neutralizing supposed witches" (Dovlo 2007, 66). For Asamoah-Gyadu, the emergence and popularity of the prosperity gospel in Africa is reinforcing not only the belief in witchcraft but it is also validating the practice of witch-hunting in many parts of Africa. Because the prosperity-gospel preachers instill in their congregants the view that God has met all human needs of health and wealth through the suffering and death of Christ, believers invoke acts of bewitchment to explain their negative life experiences (Asamoah-Gyadu 2015, 25).

Since everything experienced as inimical is attributed to witchcraft, some refer to the phenomenon as a "witchcraft mentality," which is,

a constructed interpretive scheme that attempts to account for misfortune, or anything inimical to a person's well-being, as traceable to the activities of witches. In this scheme of interpretation all causality 
is deemed to have originated primarily from the spiritual realm; the material causes are considered secondary, or seen as the medium through which the primary spiritual causality finds its expression. Such an interpretation tends to discount a material causal explanation of events, focusing attention on external agents, usually witches. This then creates a mindset that attempts to account for misfortunes not in the actions, behaviour or attitude of the victim, but rather in the activities of an enemy or malefactor. It is not uncommon to hear people exclaim in dismay in the face of problems: "Who is doing these things to me?" instead of "What is causing these things?" (Akrong 2007, 59-60).

\section{Witchcraft Accusation and Typical Victims of Such Accusations}

Because witchcraft is shrouded in secrecy it is believed that no one ever willingly admits to being a witch, they will only do so under coercion. As such, witchcraft accusations are based on suspicion, rumor, or gossip that circulate within the community whenever its members are faced with a tragedy. In many instances, when misfortunes are experienced, traditional healers and diviners are called upon to determine and explain the source of the misfortunes and also reveal the identity of the offending witch. The belief is that diviners can detect the terrible smell carried by witches (Quarmyne 2011, 480-481; Nyaga 2007, 258). An alarming element of witchcraft accusations is the stigmatization, forced exile, or even the killing of suspected witches (ter Haar 2007, 1; Akrong 2007, 65; Dovlo 2007, 72).

For some strange reasons, the face of witchcraft is primarily feminine and juvenile in the majority of African contexts. Although in most cases women, especially older women, constitute the vast majority of those accused of witchcraft (Quarmyne 2011, 476; Nyaga 2007, 257; Akrong 2007, 59), children are increasingly becoming victims of such accusations (Schnoebelen 2009, 14-17). This is in part due to the belief that witchcraft is usually inherited or learned (Nyabwari and Kagema 2014, 12). As such, children of women once accused of being witches become victims of the same type of accusations. It is suggested that "it is usually the most discriminated against and marginalised who are accused of witchcraft because they are least able to defend themselves or because they are considered of little value to society and therefore a burden to it in times of hardship" (Escribano 2011). It is argued that "the great variety in marks of identification [of witches] means that people intent on accusing others of witchcraft can always do so" (Dovlo $2007,68)$.
People are often accused of witchcraft based on particular characteristics such as old age, poor health, red or yellow eyes, wrinkled skin, missing teeth, a hunched stance, or great wealth. Children likely to be accused of witchcraft fall into the following categories: orphans who live with step parents or extended family with financial difficulties, children with any physical disability or abnormality (e.g., autism, Down Syndrome, swollen belly, red eyes), twins (associated with the occult or the anger of the gods), children whose birth is considered abnormal (premature children, awkward position during delivery), and children with albinism. Albinos are accused of witchcraft but also sought out because of the magic powers supposedly contained in their organs, hair, skin and limbs (Cimpric 2010, 2; Schnoebelen 2009, 15, 17).

Witchcraft accusations can also be triggered by other factors such as tragedy, economic wellbeing and strained relationships among community members (Mencej 2015, 114; Dovlo 2007, 69). Thus, it is reported that witchcraft accusations increase in times of social instability (Hill 1996, 325). Witch-hunts have been prompted by health crises such as HIV/AIDS, cholera, Ebola, meningitis, tetanus, and many other epidemics (Schnoebelen 2009, 19; Asamoah-Gyadu 2015, 23).

Strained relationships are also known to contribute to witchcraft accusations. It is often common for rivals to accuse each other of witchcraft practices. This is commonplace in many polygamous marital relationships where there are jealous relationships between cospouses or between mothers-in-law and daughters-inlaw who often maliciously accuse each other of witchcraft as part of their competition for either the husband or the son/husband figure (Quarmyne 2011, 479; Nyaga 2007, 257).

The same level of rivalry is also often observed between professionals, business people, politicians, and even religious leaders. Because economic wellbeing can be attributed to witchcraft, witchcraft accusations are ways of either getting rid of one's rivals or a way of justifying someone's success (Stabell 2010, 460; Dovlo 2007, 69; Nyaga 2007, 259). In other instances, there exists some form of tension between people before accusations of witchcraft occur. In these instances, the main function of the accusations is to provide people with the means of expressing and channeling the tensions as well as outlets for repressed hostility, frustration, and anxiety. In the event of a misfortune, the suspected person is often "first and foremost sought among those neighbours with whom victims had already been in problematic relationships before the misfortune occurred" (Mencej 2015, 114). 


\section{Witchcraft Accusation and the Church's Response}

In the face of the severe consequences of witchcraft accusations, what should the church do? The contributors to Mission in the $21^{t}$ Century outline five essential marks of effective mission: (1) to proclaim the good news of the Kingdom, (2) to teach, baptize, and nurture new believers, (3) to respond to human needs by loving service, (4) to seek to transform unjust structures of society, and (5) to strive to safeguard the integrity of creation and sustain and renew the life of the earth (Walls and Ross 2008). I suggest this framework be adapted in addressing issues related to witchcraft accusations.

Following are three recommendations that the church can use to start curbing the problem of witchcraft accusations:

1. In the process of teaching and nurturing believers, a special emphasis should be put on worldview change and a well-balanced approach to the truth, allegiance, and power dimensions of Christian discipleship. Worldview is the unconscious frame of reference people operate from. Since most African converts to Christianity are from an African Traditional Religions (ATR) background, when they come to Christ they are likely to interpret the Scriptures through the filter of an ATR worldview. Unless their conversion is followed by a worldview transformation, their Christian life will remain influenced by the values and core assumptions of the ATR worldview especially in times of crises. Africa is a poweroriented mission context. Change of worldview must also be accompanied by demonstrations of God's power in conjunction with coherent biblically-based arguments. Converts need a visible demonstration that the God of the Bible is more powerful than the powers of witchcraft. Unless converts from an ATR background experience at the worldview level both a truth-filled and powerfilled Christianity, many of them will "continue to seek out the old power sources to satisfy their fears and needs" (Bauer 2008, 342). There should be a steady and systematic discussion on witchcraft and the power of God to conquer evil powers in training programs both for church leaders, seminarians, and church members across the continent.

2. Because the violence, marginalization, and illtreatment of people accused of witchcraft is a breach of their human rights, church leaders should be involved in community education on human rights as well as lobbying for justice for the harm done to victims of witchcraft accusations. This can be a powerful tool for deterring community and church members alike from engaging in witch-hunting.

3. Through a partnership with the Non-Governmental Organizations, church entities should promote and participate in the rehabilitation, integration, and counseling of exiled alleged witches to help return them back to their families and communities. Efforts should be made to work toward the empowerment of those who cannot return to their communities with incomegenerating activities so they can support themselves.

\section{Bibliography}

Akrong, Abraham. 2007. A Phenomenology of Witchcraft in Ghana. In Imagining Witchcraft: Witchcraft Beliefs and Accusations in Contemporary Africa. Gerrie ter Haar, ed. Pp. 53-66. Asmara, Eritrea: Africa World Press.

Asamoah-Gyadu, Kwabena J. 2015. Witchcraft Accusations and Christianity in Africa. International Bulletin of Missionary Research 39(1):23-27.

Baloyi, M. Elijah. 2014. A Pastoral Examination of the Christian Church's Response To Fears of and Reactions to Witchcraft amongst African People in the Limpopo Province of South Africa. HTS Teologiese Studies/ Theological Studies 70, no. 2. http://dx.doi.org/10.4102/hts.v70i2.1317 Accessed October 2, 2019.

Bauer, Bruce L. 2008. A Response to Dual Allegiance. Evangelical Mission Quarterly 44:340-347.

Cimpric, Aleksandra. 2010. Children Accused of Witchcraft: An Anthropological Study of Contemporary Practices in Africa.

http://www.unicef.org/wcaro/wcaro_ children-accused-ofwitchcraft-in-Africa. pdf

Accessed October 2, 2019.

Danfulani, Umar Habila Dadem. 2007. Anger as a Metaphor of Witchcraft: The relation between Magic, Witchcraft and Divination among the Mupun of Nigeria. In Imagining Witchcraft: Witchcraft Beliefs and Accusations in Contemporary Africa. Gerrie ter Haar, ed. Pp. 143-184. Asmara, Eritrea: Africa World Press.

Dovlo, Elom. 2007. Witchcraft in Contemporary Ghana. In Imagining Witchcraft: Witchcraft Beliefs and Accusations in Contemporary Africa. Gerrie ter Haar, ed. Pp. 67-92. Asmara, Eritrea: Africa World Press. 
Ellis, Stephen and Gerrie ter Haar. 2004. Worlds of Power: Religious Thought and Political Practice in Africa. Oxford, UK: Oxford University Press.

Escribano, Judith. 2011. Violence against Older Women: Tackling Witchcraft Accusations, https://ageukblog.org.uk/2011/11/24/guest-blog-violenceagainst-older-women-tackling-witchcraft-accusations/ Accessed October 2, 2019

Harries, Jim. 2012. Witchcraft, Envy, Development, and Christian Mission in Africa. Missiology: An International Review 40(2):129-139.

Hill, Harriet. 1996. Witchcraft and the Gospel: Insights from Africa. Missiology: An International Review, 24(3):323344.

Hinfelaar, Hugo F. 2007. Witch-Hunting in Zambia and International Illegal Trade. In Imagining Witchcraft: Witchcraft Beliefs and Accusations in Contemporary Africa. Gerrie ter Haar, ed. Pp. 229-245. Asmara, Eritrea: Africa World Press.

Hutton, Ronald. 2006. Shamanism: Mapping the Boundaries. Magic, Ritual, and Witchcraft 1(2):209-213.

Magoola, Robert. 2012. Engaging Witchcraft Accusations among Christians as a Vehicle of African Traditional Religious Self-Advocacy in African Contexts. The Asbury Journal 68(1):97-107.

Mbiti, John S. 1990. African Religion \& Philosophy. Oxford, UK: Heinemann.

Mencej, Mirjam. 2015. Origins of Witchcraft Accusations. Studia Mythologica Slavica 18:111-130.

Ntloedibe-Kuswani, Gomang Seratwa. 2007. Witchcraft as a Challenge to Batswana Ideas of Community and Relationships. In Imagining Witchcraft: Witchcraft Beliefs and Accusations in Contemporary Africa. Gerrie ter Haar, ed. Pp. 205-228. Asmara, Eritrea: Africa World Press.

Nyabwari, Bernard Gechiko and Dickson Nkonge Kagema. 2014. The Impact of Magic and Witchcraft in the Social, Economic, Political and Spiritual Life of African Communities. International Journal of Humanities Social Sciences and Education 1(5):9-18.

Nyaga, Stephen Nyoka. 2007. The Impact of Witchcraft Beliefs and Practices on the Socio-Economic Development of the Abakwaya in Musoma-Rural District, Tanzania. In Imagining Witchcraft: Witchcraft Beliefs and Accusations in Contemporary Africa. Gerrie ter Haar, ed. Pp. 247-268. Asmara, Eritrea: Africa World Press.
Priest, Robert J., Abel Ngolo and Timothy Stabell. 2020. Christian Pastors and Alleged Child Witches in Kinshasa, DRC. On Knowing Humanity Journal 4(1):1-51.

Quarmyne, Maakor. 2011. Witchcraft: A Human Rights Conflict Between Customary/Traditional Laws and the Legal Protection of Women in Contemporary SubSaharan Africa. William \& Mary Journal of Women and the Law 17(2):475-507.

Stabell, Timothy D. 2010. "The Modernity of Witchcraft" and the Gospel in Africa. Missiology 38(4):460-474.

Schnoebelen, Jill. 2009. Witchcraft Allegations, Refugee Protection and Human Rights: A Review of the Evidence. Research Paper No. 169 (January):1-43. http://www.unhcr.org/4981ca712.pdf Accessed October 2, 2019.

Ter Haar, Gerrie. 2007. Introduction: The Evil Called Witchcraft. In Imagining Witchcraft: Witchcraft Beliefs and Accusations in Contemporary Africa. Gerrie ter Haar, ed. Pp. 1-30. Asmara, Eritrea: Africa World Press.

Walls, Andrew and Cathy Ross, eds. 2008. Mission in the 21" Century: Exploring the Five Marks of Global Mission. Maryknoll, New York: Orbis.

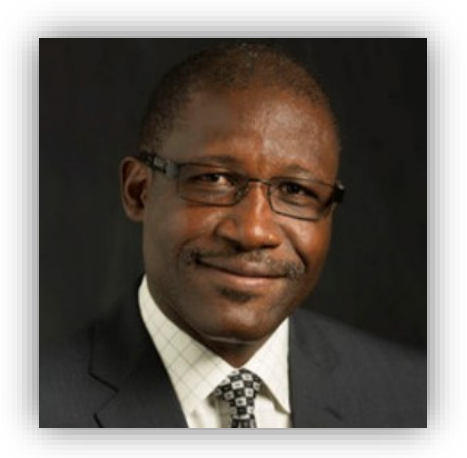

Boubakar Sanou is Assistant Professor of Mission and Leadership at the Seventh-day Adventist Theological Seminary, Andrews University.

Author email: sanou@andrews.edu 